\title{
Perancangan Aplikasi Data Mining Untuk Menentukan Pasien Menderita Tifoid Dengan Metode Algoritma C4.5
}

\author{
Yusra Fadhillah ${ }^{1}$, Muhammad Noor Hasan Siregar ${ }^{2}$, Oberlin Siagian ${ }^{3 *}$ \\ 1,2,3 Universitas Graha Nusantara, Padangsidimpuan, Indonesia \\ 1yusra.fadilah18@gmail.com, ${ }^{2}$ noor.siregar@gmail.com, ${ }^{3 *}$ berlinsiagian99@gmail.com \\ ${ }^{*}$ Email : yusra.fadilah18@gmail.com
}

\begin{abstract}
Abstrak-Data mining adalah suatu istilah yang digunakan untuk menguraikan penemuan pengetahuan didalam database. Proses data minig ini akan diimplementasikan dengan menggunakan algoritma C.45. Algoritma C.45 dapat digunakan dalam pembentukan pohon keputusan tetapi lebih mengarah pada perhitungan probabilitas dari tiap-tiap record terhadap kategori-kategori tersebut atau untuk mengklarifikasi record dengan mengelompokan ke dalam satu kelas. Setelah sebuah pohon keputusan dibangun maka dapat digunakan untuk mengklarifikasi record yang beulm ada kelasnya. Dimulai dari node root menggunakan tes terhadap atribut dari record yang belum ada kelasnya, kemudian mengikuti cabang sesuai dengan proses pohon keputusan yanitu mengubah bentuk data (table) menjadi pohon (tree) kemudian merubah model pohon tersebut menjadi aturan. Berdasarkan penelitian yang telah dilakukan yang telah dibangun dapat menentukan pasien yang menderita penyakit tipes.
\end{abstract}

Kata Kunci: Data Mining, Algoritma C.45, Decision Tree, PHP \& MySql.

\begin{abstract}
Data mining is a term used to describe the discovery of knowledge in databases. This data mining process will be implemented using the C. 45 algorithm. The C.45 algorithm can be used in the formation of decision trees but is more directed at calculating the probability of each record against these categories or to clarifying records by grouping them into one class. After a decision tree is built, it can be used to clarify records that do not yet have a class. Starting from the root node using tests on the attributes of records that do not have a class, then following the branches according to the decision tree process, which is to change the shape of the data (table) into a tree (tree) and then change the tree model into rules. Based on the research that has been done that has been built, it can determine which patients suffer from typhoid
\end{abstract}

Keywords: Data Mining, Algoritma C.45, Decision Tree, PHP \& MySql.

\section{PENDAHULUAN}

Penyakit demam Tifoid atau sering disebut dengan tifus abdominalis merupakan penyakit infeksi akut pada saluran pencernaan yang berpotensi menjadi penyakit sistemik yang disebabkan oleh salmonella [2] . Demam typhoid sendiri akan sangat berbahaya jika tidak segera ditangani secara baik dan benar, bahkan dapat menyebabkan kematian. Menurut data WHO (World Health Organization) memperkirakan angka insidensi di seluruh dunia sekitra 17 juta jiwa per tahun, angka kematian akibat demam typhoid mencapai 600.000 dan $70 \%$ nya terjadi di Asia. Di Indonesia sendiri, penyakit typhoid bersifat endemic, menurut WHO angka penderita demam typhoid di Indonesia mencapai $81 \%$ per 100.000 (Depkes RI, 2013). Berdasarkan data yang diperoleh dinas kesehatan sistem surveilans terpadu beberapa penyakit terpilih pada tahun 2010 penderita demam typhoid ada 44.422 penderita, termasuk urutan ketiga dibawah diare dan TBC selaput otak sedangkan pada tahun 2011 jumlah penderita tifoid di Sumatera Barat meningkat menjadi 46.142 penderita. Hal ini menunjukan bahwa kejadian demam typhoid di sumatera barat termasuk tinggi. Masalah utama yang sering terjadi pada pasien penderita demam typhoid antara lain adalah demam, demam sering dijumpai, biasanya demam lebih dari seminggu, pada penderita demam typhoid juga ditemui masalah mual, muntah, nyeri abdomen atau perasaan tidak enak di perut, diare [4].

Secara umum data mining adalah suatu istilah yang digunakan untuk menguraikan penemuan pengetahuan didalam database. Data mining adalah proses yang menggunakan Teknik statistic, matematika, kecerdasan buatan dan machine learning untuk mengekstraksi dan mengidentifikasi informasi yang bermanfaat dan pengetahuan yang terkait dari berbagai database besar [3].

Algoritma C4.5 merupakan struktur pohon dimana terdapat simpul yang mendeskripsikan atribut-atribut, setiap cabang menggambarkan hasil dari atribut yang diuji, dan setiap daun menggambarkan kelas. Algoritma C4.5 secara rekursif mengunjungi setiap simpul keputusan, memilih pembagian yang optimal sampai tidak bias dibagi lagi. Algoritma C4.5 menggunakan konsep information gain atau entrophy reduction untuk memilih pembagian yang optimal [5]. Pohon keputusan mirip sebuah struktur dimana terdapat node internal yang mendeskripsikan atribut-atribut, setiap cabang menggambarkan hasil dari atribut yang diuji, dan setiap daun menggambarkan kelas. Pohon keputusan bekerja mulai dari akar paling atas, jika diberikan sejumlah data uji, misalnya X dimana kelas dari data $\mathrm{X}$ belum diketahui, maka pohon keputusan akan menelusuri mulai dari akar sampai node dan setiap 
nilai dari atribut sesuai data $\mathrm{X}$ diuji apakah sesuai dengan aturan pohon keputusan , kemudian pohon keputusan akan memprediksi kelas dari tupel X [1]

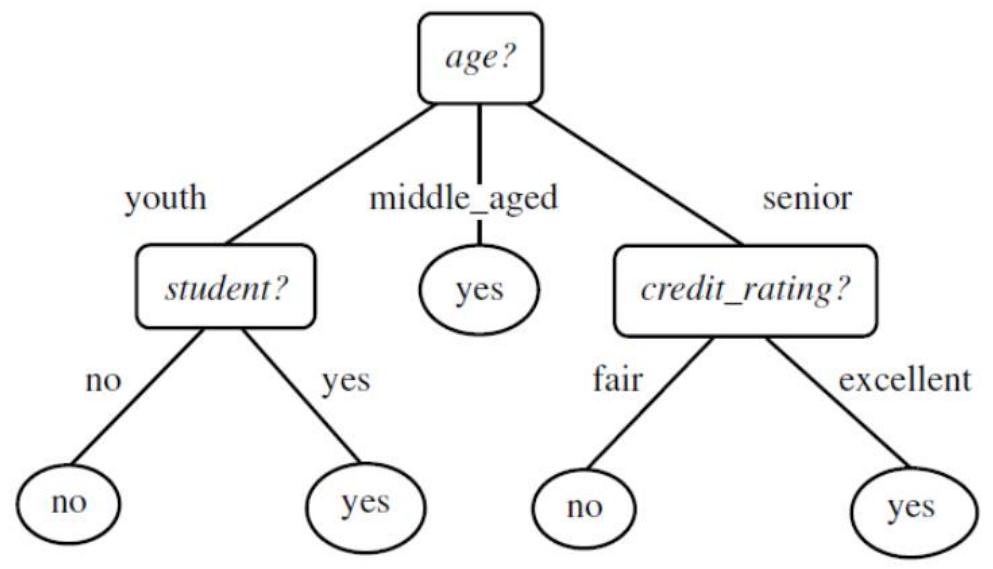

Gambar 1. Konsep Pohon Keputusan

Ada beberapa tahap dalam membuat sebuah pohon keputusan dengan algoritma $\mathrm{C} 4.5$ yaitu, [1]:

1. Menyiapkan data training. Data training biasanya diambil dari data histori yang pernah terjadi sebelumnya dan sudah dikelompokan ke dalam kelas-kelas tertentu.

2. Menentukan akar dari pohon. Akar akan diambil dari atribut yang terpilih, dengan cara menghitung nilai gain dari masing-masing atribut, nilai gain yang paling tinggi yang akan menjadi akar pertama sebelum menghitung nilai gain dan atribut, hitung dahulu nilai entrophy. Untuk mengihitung nilai entrophy digunakan rumus sebagai berikut :

Keterangan :

$$
\text { Entropi }(\mathrm{S})=\sum_{i}^{k}=1-p i \log 2 p i
$$

$\mathrm{S}=$ Himpunan Kasus

$\mathrm{K}=$ Jumlah Partisi $\mathrm{S}$

$\mathrm{Pi}=$ Probabilitas yang didapat dari jumlah (ya/tidak) dibagi total kasus

3. Menghitung nilai gain menggunakan rumus :

$$
\text { Gain }(\mathrm{S}, \mathrm{A})=\text { Entropi }(\mathrm{S})-\sum_{1}^{n}=1 \frac{S 1}{S} * \text { Entropi }(S i)
$$

Keterangan :

$\mathrm{S}=$ Himpunan Kasus

A $=$ Fitur

$\mathrm{n}=$ Jumlah partisi atribut A

$|\mathrm{Si}| \quad=$ Proporsi Si terhadap $\mathrm{S}$

$|\mathrm{S}| \quad=$ Jumlah kasus dalam $\mathrm{S}$,

4. Ulangi langkah ke-2 hingga semua record terpartisi

5. Proses partisi pohon keputusan akan berhenti saat :

a. Semua record dalam simpul $\mathrm{N}$ mendapat kelas yang sama

b. Tidak ada atribut di dalam record yang dipartisi lagi

c. Tidak ada record di dalam cabang yang kosong

\section{METODE PENELITIAN}

\subsection{Kerangka Penelitian}

Dalam melakukan penelitian, salah satu langkah yang penting yaitu membuat kerangka pemikiran, kerangka pemikiran adalah merupakan suatu strategi untuk mencapai penelitian yang teah ditetapkan dan berperan sebagai pedoman atau penuntun peneliti seluruh proses penelitian. 


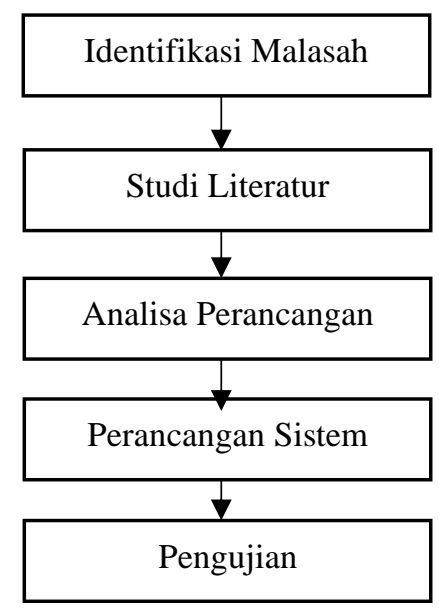

Gambar 2. Kerangka Kerja Penelitian

1. Identifikasi masalah menentukan Batasan masalah yang diteliti dan memiliki konsistensi yang terarah, serta tercapainya tujuan dari penelitian ini

2. Studi literatur dilakukan agar peneliti mencari dan mempelajari sumber-sumber pengetahuan berupa jurnaljurnal penelitian dan sumber pustaka otentik lainnya yang berkaitan dengan penelitian yaitu Algoritma C4.5, Data Mining, Typhoid dan Perancangan sistem.

3. Analisa Perancangan berupa kumpulan rangkaian data yang akan diolah dan di implementasikan ke dalam metode Algoritma C4.5

4. Perancangan sistem dilakukan untuk mendesain rancangan bentuk tampilan antarmuka, perancangan ini akan dilakukan perancangan program, perancangan sistem dilakukan setelah mendapat gambaran dengan jelas apa yang harus dikerjakan

\section{HASIL DAN PEMBAHASAN}

Khusus untuk penyakit Typhoid atribut yang digunakan adalah nama pasien, lingkungan, kondisi fisik dan makanan, dalam pengolahan data untuk memutuskan apakah seorang pasien menderita penyakit typhoid atau tidak.

Tabel 1. Data Pasien I

\begin{tabular}{|c|l|l|l|l|}
\hline No & \multicolumn{1}{|c|}{ Nama Pasien } & \multicolumn{1}{c|}{ Lingkungan } & \multicolumn{1}{c|}{ Kondisi Fisik } & \multicolumn{1}{c|}{ Makanan } \\
\hline 1 & M. Ade Putra & Tidak Bersih & Kuat & Bergizi \\
\hline 2 & Afdal Tanjung & Sangat Tidak Bersih & Sedang & Tidak Bergizi \\
\hline 3 & Almaidi Saputra & Tidak Bersih & Kuat & Bergizi \\
\hline 4 & Aldi Septian Alfino & Tidak Bersih & Sedang & Bergizi \\
\hline 5 & Amin & Sangat Tidak Bersih & Sedang & Tidak Bergizi \\
\hline 6 & Amrizal & Sangat Tidak Bersih & Lemah & Bergizi \\
\hline 7 & Riski Fernandes & Tidak Bersih & Kuat & Bergizi \\
\hline 8 & Disrizal & Bersih & Sedang & Tidak Bergizi \\
\hline 9 & Doni Satria & Tidak Bersih & Lemah & Tidak Bergizi \\
\hline 10 & Edo Rahmadani & Bersih & Kuat & Tidak Bergizi \\
\hline 11 & Ema Fatmawati & Tidak Bersih & Kuat & Bergizi \\
\hline 12 & Fadmah & Sangat Tidak Bersih & Sedang & Tidak Bergizi \\
\hline 13 & Firmansyah & Tidak Bersih & Kuat & Bergizi \\
\hline 14 & Hamzifah Rahmi & Tidak Bersih & Sedang & Bergizi \\
\hline 15 & Jufriadi & Sangat Tidak Bersih & Sedang & Tidak Bergizi \\
\hline 16 & Kahirudin & Sangat Tidak Bersih & Lemah & Tidak Bergizi \\
\hline 17 & Nanda Saputra & Tidak Bersih & Kuat & Bergizi \\
\hline 18 & Nawir & Bersih & Sedang & Tidak Bergizi \\
\hline 19 & Rahman Syahputra & Tidak Bersih & Lemah & Tidak Bergizi \\
\hline 20 & Rangga Ramadhan & Bersih & Kuat & Tidak Bergizi \\
\hline 21 & Sukardi & Bersih & Sedang & Bergizi \\
\hline 22 & Sesria Maharani & Sangat Tidak Bersih & Lemah & Tidak Bergizi \\
\hline
\end{tabular}




\begin{tabular}{|l|l|l|l|l|}
\hline \hline 23 & Suci Seviola & Tidak Bersih & Sedang & Bergizi \\
\hline 24 & Putri Awalina & Tidak Bersih & Lemah & Tidak Bergizi \\
\hline 25 & Pandi Agung & Bersih & Sedang & Bergizi \\
\hline 26 & Pandra Pratama & Bersih & Sedang & Bergizi \\
\hline 27 & Usnatun & Tidak Bersih & Lemah & Tidak Bergizi \\
\hline 28 & Yuni Rahma & Sangat Tidak Bersih & Lemah & Tidak Begizi \\
\hline 29 & Yuliarti & Tidak Bersih & Kuat & Bergizi \\
\hline 30 & Ziko Setiawan & Bersih & Kuat & Bergizi \\
\hline
\end{tabular}

Langkah - langkah algoritma C4.5 :

1. Pilih atribut sebagai akar (root).

Dalam menentukan akar (root) perlu dilakukan pencarian nilai entrophy dan nilai gain. Nilai gain yang tertinggi akan dijadikan sebagai akar (root)

2. Buat cabang untuk tiap-tiap nilai berdasarkan atribut yang ada, untuk membuat cabang dilakukan dengan pencarian nilai entrophynya

3. Bagi kasus kedalam cabang pada decision tree

4. Ulangi proses untuk semua cabang memiliki kelas yang sama.

Hal pertama yang dilakukan adalah melakukan pencarian entrophy, kemudian dilanjukan dengan pencarian gain dengan rumus yang telah disediakan. Gain yang tertinggi akan menjadi akar, dari hasil pencarian diatas diimplementasikan kedalam tabel seperti berikut :

Tabel 2. Pencarian Entrophy Iterasi I

\begin{tabular}{|c|c|c|c|c|c|c|}
\hline No & Node & Jumlah & $\mathbf{Y a}$ & Tidak & Entrophy & Gain \\
\hline 1 & Total & 30 & 12 & 18 & 0.9709 & \\
\hline \multirow{3}{*}{2} & Makanan & & & & & \multirow{3}{*}{0.2716} \\
\hline & Bergizi & 16 & 2 & 14 & 0.5897 & \\
\hline & Tidak bergizi & 14 & 10 & 4 & 0.8247 & \\
\hline \multirow{4}{*}{3} & Lingkungan & & & & & \multirow{4}{*}{0.5681} \\
\hline & Bersih & 8 & 0 & 8 & 0 & \\
\hline & Tidak BErsih & 14 & 4 & 10 & 0.8246 & \\
\hline & Sangat Tidak Bersih & 8 & 8 & 0 & 0 & \\
\hline \multirow{4}{*}{4} & Kondisi Fisik & & & & & \multirow{4}{*}{0.5856} \\
\hline & Kuat & 10 & 0 & 10 & 0 & \\
\hline & Sedang & 12 & 4 & 8 & 0.9633 & \\
\hline & Lemah & 8 & 8 & 0 & 0 & \\
\hline
\end{tabular}

Dari tabel diatas atribut yang mempunyai nilai gain tertinggi dijadikan sebagai node akar, dimana kondisi fisik yang memiliki nilai gain tertinggi yang akan menjadi akar dari pohon keputusan sebagai berikut:

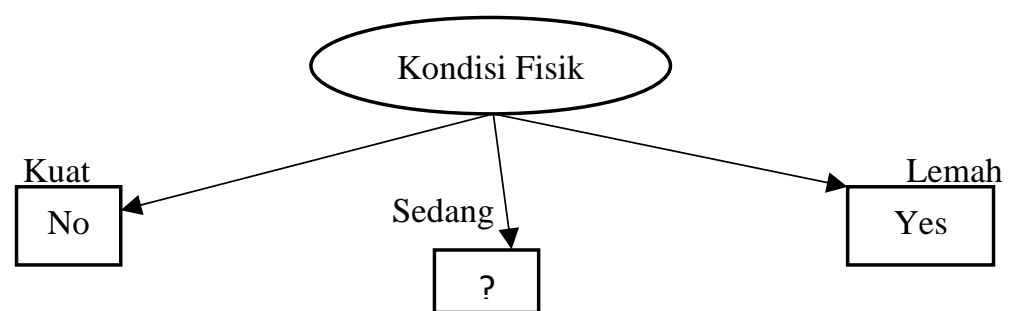

Gambar 3. Pohon Keputusan 1

Berdasarkan gambar diatas pohon keputusan dapat disimpulkan bahwa kondisi fisik mempengaruhi pasien yang menderita penyakit typhoid. Pasien yang memiliki kondisi fisik lemah maka pasien tersebut dikatakan dapat menderita penyakit typhoid, jika kondisi fisik pasien kuat maka pasien tersbut tidak menderita penyakit typhoid 
Tabel 3. Data Pasien II

\begin{tabular}{|c|l|c|l|l|l|}
\hline No & \multicolumn{1}{|c|}{ Nama Pasien } & $\begin{array}{c}\text { Kondisi } \\
\text { Fisik }\end{array}$ & \multicolumn{1}{|c|}{ Lingkungan } & Makanan & Keputusan \\
\hline 1 & Afdal Tanjung & Sedang & $\begin{array}{l}\text { Sangat Tidak } \\
\text { Bersih }\end{array}$ & Tidak Bergizi & Ya \\
\hline 2 & Almaidi Saputra & Sedang & Tidak Bersih & Bergizi & Tidak \\
\hline 3 & Amin & Sedang & $\begin{array}{l}\text { Sangat Tidak } \\
\text { Bersih }\end{array}$ & Tidak Bergizi & Ya \\
\hline 4 & Disrizal & Sedang & Bersih & Tidak Bergizi & Tidak \\
\hline 5 & Fadmah & Sedang & $\begin{array}{l}\text { Sangat Tidak } \\
\text { Bersih }\end{array}$ & Tidak Bergizi & Ya \\
\hline 6 & Hana Zifah & Sedang & Tidak Bersih & Bergizi & Tidak \\
\hline 7 & Jufriadi & Sedang & $\begin{array}{l}\text { Sangat Tidak } \\
\text { Bersih }\end{array}$ & Tidak Bergizi & Ya \\
\hline 8 & Nawir & Sedang & Bersih & Tidak Bergizi & Tidak \\
\hline 9 & Sukardi & Sedang & Bersih & Bergizi & Tidak \\
\hline 10 & Suci Seviola & Sedang & Tidak Bersih & Bergizi & Tidak \\
\hline 11 & Pandra Pratama & Sedang & Bersih & Bergizi & Tidak \\
\hline
\end{tabular}

Kemudian dilanjutkan dengan pencarian entrophy dan gain untuk iterasi II

Tabel 4. Pencarian Entrophy Iterasi II

\begin{tabular}{|c|c|c|c|c|c|c|}
\hline No & Node & Jumlah & $\mathbf{Y a}$ & Tidak & Entrophy & Gain \\
\hline 1 & Total & 12 & 4 & 8 & 0.9633 & 0 \\
\hline \multirow{4}{*}{2} & Lingkungan & & & & & \multirow{4}{*}{0} \\
\hline & Bersih & 5 & 0 & 5 & 0 & \\
\hline & Tidak Bersih & 3 & 0 & 3 & 0 & \\
\hline & $\begin{array}{ll}\text { Sangat } & \text { Tidak } \\
\text { Bersih } & \\
\end{array}$ & 4 & 4 & 0 & 0 & \\
\hline \multirow{3}{*}{3} & Makanan & & & & & \multirow{3}{*}{0.4817} \\
\hline & Bergizi & 6 & 0 & 6 & 0 & \\
\hline & Tidak Bergizi & 6 & 4 & 2 & 0 & \\
\hline
\end{tabular}

Dari tabel diatas atribut yang memiliki nilai gain tertinggi dijadikan sebagai node akar, dimana makanan yang memiliki nilai gain tertinggi yang akan menjadi akar dari pohon keputusan sebagai berikut :

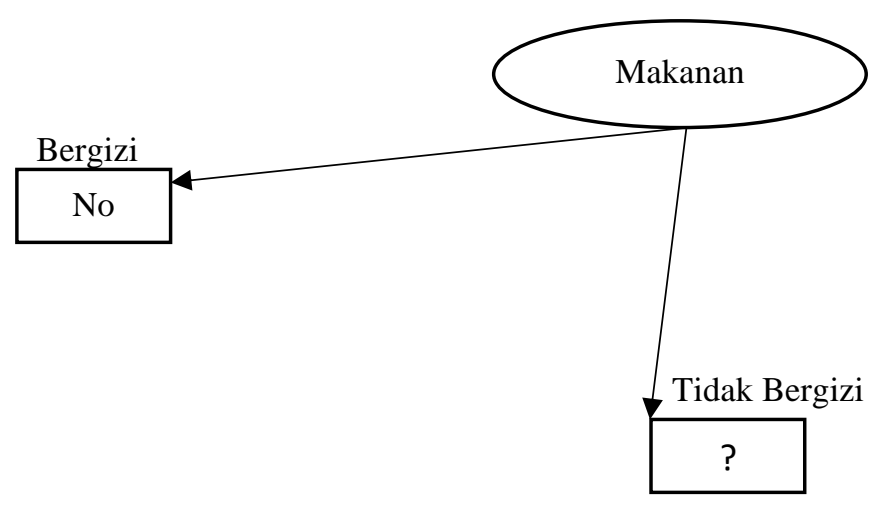

Gambar 4. Pohon Keputusan 2 
Berdasarkan gambar diatas makanan juga mempengaruhi seorang pasien menderita penyakit Typhoid, jika pasien yang memiliki tanda- tanda Typhoid pada makanan tertentu dengen kategori makanan bergizi maka pasien tersebut tidak menderita penyakit Typhoid.

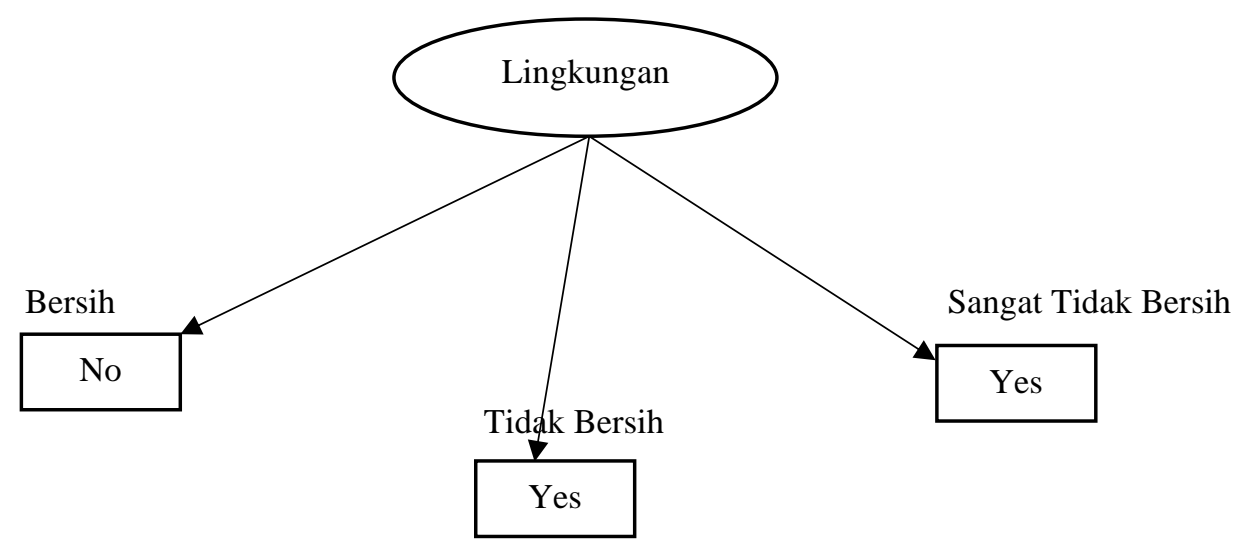

Gambar 5. Pohon Keputusan 3

Berdasarkan gambar diatas lingkungan juga mempengaruhi seorang pasien menderita penyakit Typhoid, jika lingkungan pasien tidak bersih maka pasien tersebut dapat dikatakan menderita penyakit Typhoid, jika lingkungan pasien sangat tidak bersih maka pasien tersebut menderita penyakit Typhoid, dan jika jika lingkungan pasien bersih maka pasien tersebut tidak menderita Typhoid. Dari kedua itersi tersebut dapat dihasilkan pohon keputusan sebagai berikut:

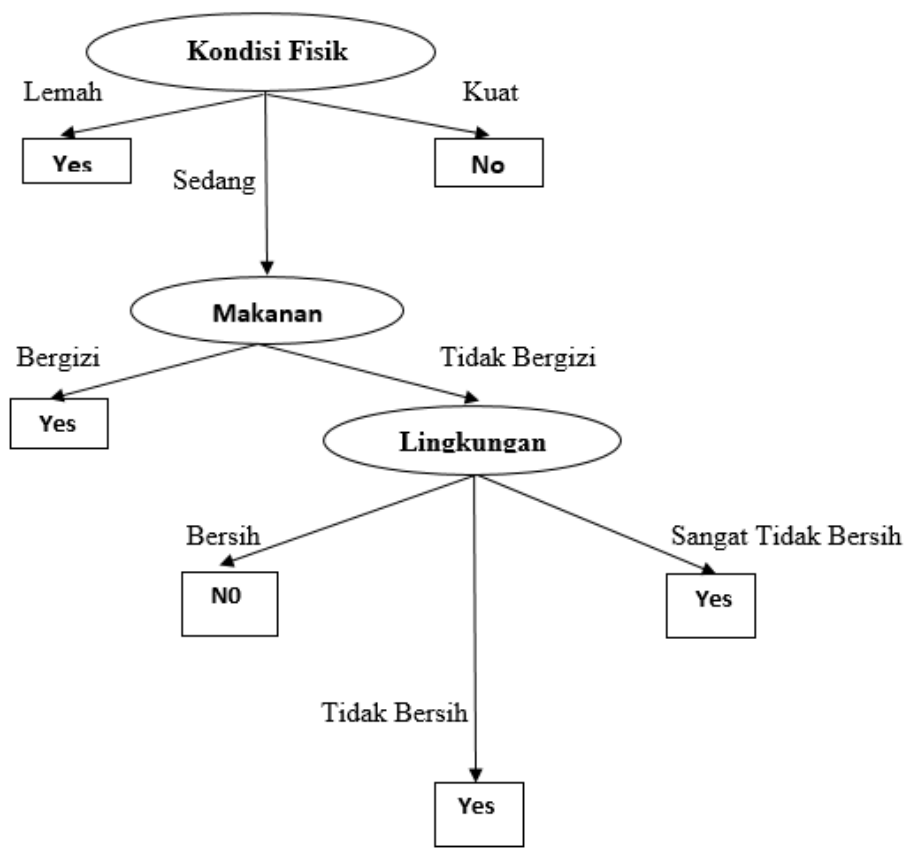

Gambar 6. Hasil Pohon Keputusan

Pengujian dan implementasi bertujuan untuk melihat apakah aplikasi yang dirancang sudah sesuai dengan apa yang diinginkan atau belum, setelah dilakukannya pengujian dan implementasi maka kualitas sebuah aplikasi akan terlihat, tampilan aplikasi dapat dilihat step-by step yang menjelaskan tentang proses dimulainya sampai aplikasi ini selesai digunakan 


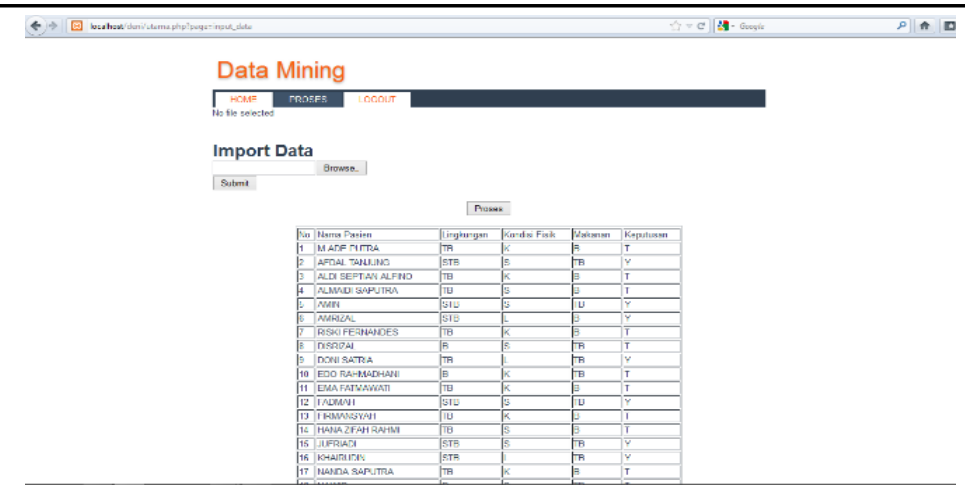

Gambar 7. Halaman Import Data

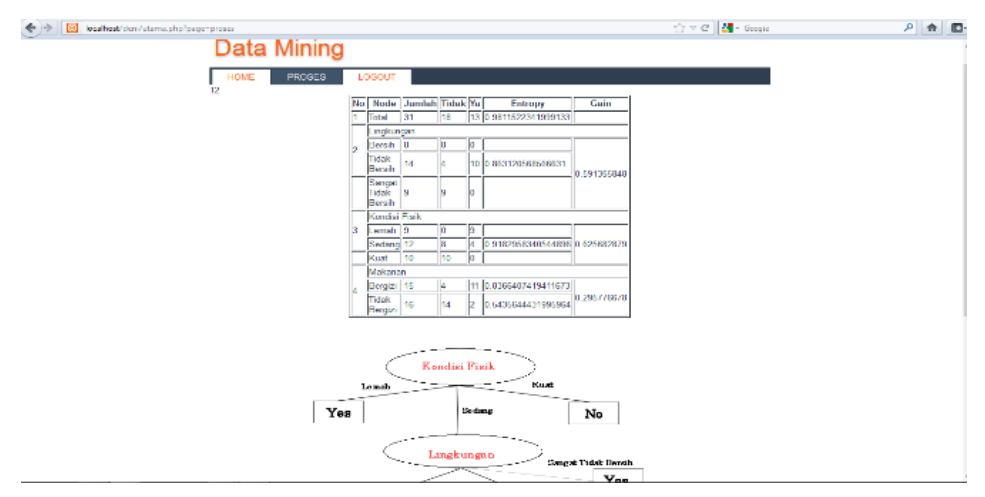

Gambar 8. Halaman Proses dan Hasil

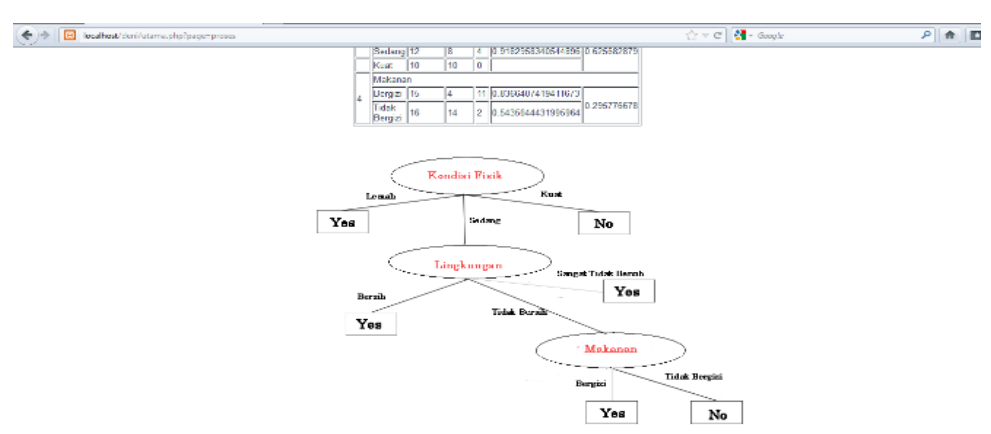

Gambar 9. Halaman Tampilan Pohon Keputusan Akhir 


\section{KESIMPULAN}

Ada beberapa kesimpulan yang bias diambil dari penelitian ini, antara lai :

1. Dengan menerapkan aplikasi data mining, dokter dapat menentukan seorang pasien menderita penyakit typhoid atau tidak dengan cara melakukan panggilan data pasien yang ada pada database, kemudian dilakukan Analisa oleh aplikasi data mining

2. Dengan menerapkan aplikasi data mining dapat memprediksi pasien yang menderita penyakit Typhoid atau tidak dengan lebih cepat dan efisien. Penggunaan aplikasi data mining ini lebih cepat dan efisien dibandingkan dengan pendekteksiaan secara manual yang memakan waktu dan kurangnya keefisien dalam mengolah data pasien. Dengan aplikasi data mining ini Dokter cukup memangil data pasien yang telah ada dan dilakukan analisa oleh aplikasi data mining ini.

3. Dengan menerapkan aplikasi data mining dapat membantu Dokter dalam mengambil keputusan seorang pasien menderita penyakit Typhoid atau tidak menderita penyakit Typhoid. Dokter cukup memanggil data pasien didalam data base kemudian dilakukan analisa oleh aplikasi ini, maka akan mengeluarkan input berupa pohon keputusan dimana hasil akan terlihat apakah seorang pasien tersebut memiliki prediktor ataupun atribut- atribut yang menjadi penyebab penyakit Typhoid atau tidak dan aplikasi ini akan mengeksekusi data dengan pilihan ya atau tidak.

4. Dengan menerapkan aplikasi data mining dapat menghasilkan informasi yang bermanfaat bagi pihak rumah sakit dan pasien. Informasi yang dihasilkan bisa berupa faktor- fakor yang menjadi penyebab penyakit Typhoid dan cara pendeteksian penyakit Typhoid mengunakan aplikasi data mining.

\section{REFERENCES}

[1] Kusriani dan Emha Taufiq Lutfi (2009). “Algoritma Data Mining” Yogyakarta : Andi

[2] Cahyono, S. B (2010). Vaksinasi Cara Ampuh Cegah Penyakit Infeksi. Yogyakarta : Kanisisus

[3] Turban (2009). "Sistem Informasi Manajemen". Pustaka Binaman Pressindo, Jakarta.

[4] Nani dan Muzakir (2014). Kebiasaan Makan dengan Kejadian Demam typhoid pada anak, Journal of Pediatric Nursing

[5] Han, J..Kamberm M., dan Pei, J. (2011) Data Mining Consepts and Techniques Third Edition. Waltham: Elsevier Inc.

[6] Rosa A., S dan M., Shalahuddin (2013). Rekayasa Perangkat Lunak, Bandung : INFORMATIKA.

[7] Mulyanto, Anur R., (2008). Rekayasa Perangkat Lunak 1, Jakarta : Direktorat Pembinaan Sekolah Menengah Kejuruan.

[8] Aunur Rofiq Mulyanto (2008). Rekayasa Perangkat Lunak 2, Jakarta : Direktorat Pembinaan Sekolah Menengah Kejuruan. 